Citations of current literature are arranged in outline form so that readers may easily find the particular articles in which they are interested. The literature on Human Experimental Psychology is divided into two parts, with each part appearing in alternate months. The part covered here consists of Human Memory, Learning, and Thinking. The part to be published next month will consist of citations on Perception, Performance, and Experimental Social Psychology. The principal headings used are given on the cover along with page references.

\section{HUMAN LEARNING}

BUGELSKI, B. R. (State Univ. of New York, Buffalo, N.Y. 14226), \& LATTANZIO, S. A culture-free learning task. Journal of Experimental Psychology, 1972, 93, 354-356.

CHERNIK, D. A. (Univ. of Pennsylvania, Philadelphia, $\mathrm{Pa}$. 19104). Effect of REM sleep deprivation on learning and recall by humans. Perceptual \& Motor Skills, 1972, 34, 283-294.

ROSS, H. S. (Univ. of North Carolina, Chapel Hill, N.C. 27514), R HE INGOLD, H. L., \& ECKERMAN, C. O. Approach and exploration of a novel alternative by 12 -month-old infants. Journal of Experimental Child Psychology, 1972, 13, 85-93.

NOBLE, C. E., \& WARREN, C. A. (Univ. of Illinois, Champaign, Ill. 61820). Human selective learning as a joint function of response alternation and response availability. Journal of Motor Behavior, 1972, 4, 57-69.

WEITZ, J.' (New York Univ., New York, N.Y. 10003). When do you stop training, or boys and girls together? Psychonomic Monograph Supplement, 1972, 4(12, Whole No. 60).

WICKER, A. W. (Claremont Grad. Sch., Claremont, Calif. 91711). Processes which mediate behavior-environment congruence. Behavioral Science, 1972, 17, 265-277.

\section{CONDITIONING}

BURSTEIN, K. R. (Simon Fraser Univ., Burnaby 2, B.C., Canada), \& SMITH, B. D. The latency distribution of the skin conductance response as a function of the CS-UCS interval. Psychophysiology, 1972, 9, 14-20.

CHAPMAN, C. R. (Dept. of Anesthesiol., Univ. of Washington Sch. of Med., Seattle, Wash. 98105), \& FEATHER, B. W. Modification of perception by classical conditioning procedures. Journal of Experimental Psychology, 1972, 93, 338-342.
CLIFTON, R. (Univ. of Massachusetts, A mherst, Mass. 01002 ), SIQUELAND, E. R., \& LIPSITT, L. $P$. Conditioned headturning in human newborns as a function of conditioned response requirements and states of wakefulness. Journal of Experimental Child Psychology, $1972,13,43-57$.

CLIFTON, R. K. (Univ. of Massachusetts, Amherst, Mass. 01002), MEYERS, W. J., \& SOLOMONS, G. Methodological problems in conditioning the headturning response of newborn infants. Journal of Experimental Child Psychology, 1972, 13, 29-42.

DRONSEJKO, K. (Lakeshore Psychiat. Hosp., 3131 Lakeshore Blvd. W., Toronto 510, Ont., Canada). Effects of CS duration and instructional set on cardiac anticipatory responses to stress in field dependent and independent subjects. Psychophysiology, 1972, 9, 1-13.

GRICE, G. R. (Univ. of New Mexico, Albuquerque, N. Mex. 87106), HENRIKSEN, K., \& SPEISS, J. M. Response mediated generalization in eyelid conditioning with reduced conflicting information. Journal of Experimental Psychology, 1972, 92, 398-404.

MARUM, K. D. (Acadia Univ., Wolfville, N.S., Canada), MACINTYRE, J., \& ARMSTRONG, R. Heart-rate conditioning, time estimation, and arousal level: Exploratory study. Perceptual \& Motor Skills, 1972, 34, 244.

MOFFAT, G. H. (Univ. of Southern Mississippi, Hattiesburg, Miss. $39401)$. Avoidance conditioning in young children with interruption of a positive stimulus as the aversive event. Journal of Experimental Child Psychology, 1972, 13, 21-28. OYAMADA, T. (Gifu Univ., Gifu, Japan). The effects of the visual attention on the acquisition of the conditioned eyelid response. Tohoku Psychologica Folia, 1971, Tomus XXX, 69-74.

TOMLINSON-KEASEY, C. (Trenton State Coll., Trenton, N.J. 08625).
Conditioning of infant vocalizations in the home environment. Journal of Genetic Psychology, 1972, 120, 75-82.

\section{DISCRIMINATION}

BERCH, D. B. (Dept. of Educational Foundations, Univ. of New Mexico, Albuquerque, N. Mex. 87106). Stimulus interaction and problem difficulty in children's discrimination learning. Journal of Experimental Child Psychology, 1972, 13, 115-127.

CAMPIONE, J. C. (Children's Rsch. Ctr., Univ. of Illinois at Urbana-Champaign, Champaign, Ill. 61820), \& BEATON, V. L. Transfer of training: Some boundary conditions and initial theory. Journal of Experimental Child Psychology, 1972, 13, 94-114.

COPPINGER, N. W. (Rsch. Unit on Aging, VA Ctr., Bay Pines, Fla. $33504)$, \& NEHRKE, M. F. Discrimination learning and transfer of training in the aged. Journal of Genetic Psychology, 1972, 120, 93-102.

GELLER, E. S. (Virginia Polytech. Inst. \& State Univ., Blacksburg, Va. 24061), WHITMAN, C. P., \& McGUIRE, G. J. Incentive effects in the discrimination of two simultaneously occurring probability distributions. Journal of Experimental Psychology, 1972, 93, 392-397.

KENDLER, H. H. (Univ. of California, Santa Barbara, Calif. 93106), GLASMAN, L. D., \& WARD, J. W. Verbal-labeling and cue-training in reversal-shift behavior. Journal of Experimental Child Psychology, 1972, 13, 195-209.

KNOWLES, B. A. (Inst. of Behav. Sci., Univ. of Colorado, Boulder, Colo. 80302 ), HAMMOND, K. R., STEWART, T. R., \& SUMMERS, D. A. Detection of redundancy in multiple cue probability tasks. Journal of Experimental Psychology, 1972, 93, 425-427.

LeMAY, E. H. (Plattsburgh State Univ. Coll. of Arts \& Sci., Plattsburgh, N.Y. 12901 ). Stimulus generalization variables in anagram-problem solving. Journal of Experimental Psychology, 1972, 93, 349-353. 
MacKINNON, M. M. (VA Hosp., Tucson, Ariz. 85723 ). Adaptation-level theory, anchor theory, and the peak-shift phenomenon. Journal of Motor Behavior, 1972, 4, 1-12.

MARX, M. H. (Univ. of Missouri, Columbia, Mo. 65201), WITTER, D. W., \& MUELLER, J. H. Additional data on probability of error repetition following varying numbers of successive prior repetitions. Perceptual \& Motor Skills, 1972, 34, 525-526.

NEWMAN, F. L. (Univ. of Miami, Coral Gables, Fla. 33124 ), ANDREONE, C. F., WASHBURN, L., \& PURTLE, R. B. Multidimensional stimulus control: Effects of training and/or testing. Journal of Experimental Psychology, 1972, 93, 290-296.

NICHOLSON, J. N. (Univ. of Reading, Reading, England), \& GRAY, J. A. Peak shift, behavioural contrast and stimulus generalization as related to personality and development in children. British Journal of Psychology, 1972, 63, 47-62.

GUSINOW, J. F., \& PRICE, L. E. (Univ. of New Mexico, Albuquerque, N. Mex. 87106). Modification of form and color responding in young children as a function of differential reinforcement and verbalization. Journal of Experimental Child Psychology, 1972, 13, 145-153.

REESE, H. W. (West Virginia Univ., Morgantown, W. Va. 26505). Acquired distinctiveness and equivalence of cues in young children. Journal of Experimental Child Psychology, 1972, 13, 171-182.

SNODGRASS, J. G. (38 Philosophy Hall, New York Univ., University Heights, Bronx, N.Y. 10453). Matching patterns vs matching digits: The effect of memory dependence and complexity on "same"."different" reaction times. Perception \& Psychophysics, 1972, 11, 341-349.

\section{VERBAL LEARNINC}

FINGERET, A. L., \& BROGDEN, W. J. (Univ. of Wisconsin, Madison, Wis. 53706). Item arrangement effects on transfer and serial position errors in part-whole leaming of different materials. Journal of Experimental Psychology, 1972, 93, 249-255.

BRUDER, G. (State Univ. of New York, Buffalo, N.Y. 14226), \& SEGAL, E. Effects of temporal and spatial organization of lists in clustering. Journal of Experimental Psychology, 1972, 93, 151-155.

MURDOCK, B. B. (Univ. of Toronto, Toronto, Ont., Canada), DUFTY, P.
O., \& OKADA, R. Using the PDP-12 in verbal learning and short-term memory research. Behavior Rese a r ch M e thods \& Instrumentation, 1972, 4, 70-71.

ROBERTS, W. A. (Univ. of Western Ontario, London 72, Ont., Canada). Free recall of word lists varying in length and rate of presentation: $A$ test of total-time hypotheses. Journal of Experimental Psychology, 1972, 92, 365-372.

WILKES, A. L. (Univ. of Dundee, Dundee, Scotland), LLOYD, P., \& SIMPSON, I. Pause measures during reading and recall in serial list learning. Quarterly Journal of Experimental Psychology, 1972, 24, 48-54.

WINOGRAD, E. (Emory Univ., Atlanta, Ga. 30322), \& RAINES, S. $R$. Semantic and temporal variation in recognition memory. Journal of Verbal Learning \& Verbal Behavior, $1972,11,114-119$.

Paired-Associate Learning

ROGERS, J. L., \& BATTIG, W. F. (Univ. of Colorado, Boulder, Colo. $80302)$. Effect of amount of prior free recall learning on paired-associate transfer. Journal of Experimental Psychology, 1972, 92, 373-377.

HALL, R. F. (Univ. of Sydney, Sydney, N.S.W., Australia 2006), \& WENDEROTH, P. M. Effects of number of responses and recall strategies on parameter values of a paired-associate learning model. Journal of Verbal Learning \& Verbal Behavior, 1972, 11, 29-37. HIPPLE, R. (Univ. of California Berkeley, Calif. 94720). Retention of paired associates as a function of list length. Journal of Experimental Psychology, 1972, 92, 435-437.

COLE, L. E., \& KANAK, N. J. (Univ. of Oklahoma, Norman, Okla. 73069). Paired-associate learning and bidirectional associative recall in first, third, fifth, and seventh graders. Journal of Experimental Child Psychology, 1972, 13, 128-137.

KINTSCH, W. (Univ. of Colorado, Boulder, Colo. 80302). Abstract nouns: Imagery versus lexical complexity. Journal of Verbal Learning \& Verbal Behavior, 1972, $11,59-65$.

MUELLER, D. J. (Univ. of Wisconsin-Milwaukee, Milwaukee, Wis. 53201), \& GUMINA, J. M. Meaningfulness of objects and trigrams as paired-associate stimulus and response. Perceptual \& Motor Skills, 1972, 34, 187-193.

MUELLER, D. J. (Univ. of Wisconsin-Milwaukee, Milwaukee, Wis. 53201), CHAN, A., \& GUMINA, J. M. Methodological studies in paired-associate learning I. Procedure, design, and meaningfulness. Perceptual \& Motor Skills, 1972, 34, 387-395.

MUELLER, D. J. (Univ. of Wisconsin-Milwaukee, Milwaukee, Wis. 53201), GUMINA, J. M., \& CHAN, A. Methodological studies in paired-associate learning: II. Design, test for learning, and meaningfulness. Perceptual \& Motor Skills, 1972, 34, 399-413.

NELSON, D. L. (Univ. of South Florida, Tampa, Fla. 33620), BROOKS, D. H., \& FOSSELMAN, J. R. Words as sets of features: Processing phonological cues. Journal of Experimental Psychology, 1972, 92, 305-312.

SILVERSTEIN, A. (Univ. of Rhode Island, Kingston, R.I. 02881). Acquired pleasantness and paired-associate learning in mixed and homogeneous lists. Journal of Experimental Psychology, 1972, 93, 111-117.

THOMSON, W. J. (Vanderbilt Univ., Nashville, Tenn. 37203). Effect of number of response categories on d i m e n s o n s e le ction, paired-associate learning, and complete learning in a conjunctive concept identification task. Journal of Experimental Psychology, 1972, 93, 95-99.

Verbal Discrimination Learning

BROTSKY, S. J. (San Fernando Valley State Coll., Northridge, Calif. 91324), \& LITWIN, L. M. Semantic generalization: Replication of Cramer's associative gradient. Journal of Experimental Psychology, 1972, 93, 430-432.

CROMER, R. F. (MRC Developmental Psychology Unit, London, England). The learning of surface structure clues to deep structure by a puppet show technique. Quarterly Journal of Experimental Psychology, 1972, 24, 66-76.

GAMBONI, W. R. (Chicago State Univ., Chicago, Ill. 60621), GAUSTAD, G. R., \& WILSON, B. E. Verbal discrimination learning as a function of percentage occurrence of reinforcing information (\% ORI) and varying presentation rates. Journal of Experimental Psychology, 1972, 93, 256-261.

HOLLY, F. (Michigan State Univ., East Lansing, Mich. 48823), \& NUISMER, W. Horizontal vs vertical letter arrangement and ease of word recognition. Perceptual \& Motor Skills, 1972, 34, 652 .

JOHNSON-I.AIRD, P. N. (University Coll., London, England), \& TRIDGELL, J. M. When negation is easier than affirmation. Quarterly Journal of Experimental Psychology, 1972, 24, 87-91. 
KANAK, N. J. (Univ. of Oklahoma, Norman, Okla. 73069), COLF, L. E., \& ECKERT E. Implicit associative responses in verbal discrimination acquisition. Journal of Experimental Psychology, 1972, 93, 309-319.

KOLLASCH, S. F., \& KAUSLER, D. H. (Univ, of Missouri, Columbia, Mo. 65201). Recognition learning of homophone. Journal of Experimental Psychology, 1972, 92, 432-434.

LEVIN, I. P. (Univ, of Iowa, lowa City, Iowa 52240), DULBERG, C. S., DOOLEY, J. F., \& HINRICHS, J. V. Sequential dependencies in single-item and multiple-item probability learning. Journal of Experimental Psychology, 1972, 93, 262-267.

MILLER, A. (Oregon System of Higher Ed., DCE, P.O. Box 3175, Eugene, Oreg. 97403), \& ERTLE, S. Is meaning conditioning effective only for words and neutral meaning? Journal of General Psychology, 1972, 86, 55-62.

ROWE, E. J. (Memorial Univ. of Newfoundland, St. John's, Nfld., Canada), \& PAIVIO, A. Effects of noun imagery, pronunciation, method of presentation, and intrapair order of items in verbal discrimination. Journal of Experimental Psychology, 1972, 93, 427-429.

SCHUTZ, S. R. (Gordon Coll., Wenham, Mass. 01984), \& KEISLAR, E. R. Young children's immediate memory of word classes in relation to social class. Journal of Verbal Learning \& Verbal Behavior, 1972, 11, 13-17.

UNDERWOOD, B. J. (Northwestern Univ., Evanston, Ill. 60201), S H A U G H NESSY, J. J., \& ZIMMERMAN, J. Learning-to-learn verbal-discrimination lists. Journal of Verbal Learning \& Verbal Behavior, 1972, 11, 96-104.

UNDERWOOD, B. J. (Northwestern Univ., Evanston, Ill. 60201), SHAUGH NESSY, J. J., \& ZIMMERMAN, J. List length and method of presentation in verbal discrimination learning with further evidence on retroaction. Journal of Experimental Psychology, 1972, 93, 181-187.

WEARING, A. J. (Yale Univ., New $\mathrm{H}$ aven, Conn. 06520 ). Remembering complex sentences. Quarterly Journal of Experimental Psychology, 1972, 24, 77-86.

\section{REINFORCEMENT}

AIKEN, L. S. (Temple Univ., Philadelphia, Pa. 19122), SANTA, J. L., \& RUSKIN, A. B. Nonreinforced trials in concept identification: Presolution statistics and local consistency. Journal of
Experimental Psychology, 1972, 93, 100-104.

BAIRD, I. S. (Auburn Univ., Auburn. Ala. 36833), \& HUGHES, G. H. Effects of frequency and specificity of information feedback on acquisition and extinction of a positioning task. Perceptual \& Motor Skills, 1972, 34, 567-572.

BERGER, S. M. (Univ. of Massachusetts, Amherst, Mass. 01002). Locus of control and the effectiveness of direct and vicarious reinforcement. Psychonomic Science, 1972, 26, 345-346.

DeCASPER, A. J. (Emory Univ., Atlanta, Ga. 30322), \& ZEILER, M. D. Steady-state behavior in children: A method and some data. Journal of Experimental Child Psychology, 1972, 13, 231-239.

EDWARDS, J. S. (Univ. of Missouri-Kansas City, Kansas City, Mo. 64100), \& UPP, L. Conjugate reinforcement of differential responding. Psychological Reports, 1972, 30, 91-98.

FAW, T. T. (Univ. of California, Los Angeles, Calif. 90024), \& PARKER, R. K. Acquisition and generalization of conditioned reward value. Psychological Reports, 1972, 30, 167-170.

HILLMAN, D. (Univ. of Nebraska, Lincoln, Neb. 68503), \& BRUNER, J. S. Infant sucking in response to variations in schedules of feeding reinforcement. Journal of Experimental Child Psychology, $1972,13,240-247$.

JACOBS, M. (West Virginia Med. Ctr., Dept. of Behav. Med. \& Psychiat.,

\section{HUMAN MEMORY}

SWANSON, J. M., JOHNSEN, A. M., \& BRIGGS, G. E. (Human Perf. Ctr., Ohio State Univ., Columbus, Ohio 43210). Recoding in a memory search task. Journal of Experimental Psychology, 1972, 93, $1-9$.

CHOVAN, W. L. (Western Carolina Univ., Cullowhee, N.C. 28723). Role of vocal labeling in memory for object arrangements by deaf and hearing children. Perceptual \& Motor Skills, 1972, 34, 59-62.

DOBBS, A. R. (Univ. of Alberta, Edmonton, Alta., Canada). Effect of retention interval, retroactive inhibition, and proactive inhibition on mediating associations. Joumal of Experimental Psychology, 1972, 93, 417-424.

DRACHMAN, D. A. (Dept. of Neurol., Northwestern Univ.-McGaw Med. Ctr., 303 E. Chicago Ave., Chicago, III. 60611), \& LEAVITT, J. Memory impairment in the aged:
Morgantown, W. Va. 26505), \& TIBER, N. Effects of internal and external control of reinforcement on binary-choice probability learning. Psychological Reports, $1972,30,255-260$.

MUELLER, D. J. (Univ. of Wisconsin-Milwaukee, Milwaukee, Wis. 53201), \& GUMINA, J. M. Methodological studies involving reward and punishment in human learning: I. Effects of design and instructions. Perceptual \& Motor Skills, 1972, 34, 63-74.

GUSINOW, J, F., \& PRICE, L. E. (Univ. of New Mexico, Albuquerque, N. Mex. 87106). Modification of form and color responding in young children as a function of differential reinforcement and verbalization. Journal of Experimental Child Psychology, 1972, 13, 145-153.

SCHWARTZ, G. E. (Dept. of Soc. Rel., Harvard Univ., Cambridge, Mass. 02138). Voluntary control of human cardiovascular integration and differentiation through feedback and reward. Science, $1972,175,90-93$.

SILVERSTEIN, A. (Univ. of Rhode Island, Kingston, R.I. 02881). Secondary reinforcement in infants. Journal of Experimental Child Psychology, 1972, 13, 138-144.

STRIEFEL, S. (Parsons Rsch. Ctr., Parsons State Hosp. \& Trng. Ctr., Parsons, Kans. 67357). Timeout and concurrent fixed-ratio schedules with human subjects. Journal of the Experimental Analysis of Behavior, $1972,17,213-219$.
Storage versus retrieval deficit. Journal of Experimental Psychology, 1972, 93, 302-308.

DUMAS, J. (Oakland Univ., Rochester, Mich. 48063). Scanning memory for multidimensional stimuli with extended practice. Perception \& Psychophysics, 1972, 11, 209-212.

EPSTEIN, W. (Univ. of Wisconsin, Madison, Wis. 53706). Retention of adaptation to uniocular image magnification: Effect of interpolated activity. Journal of Experimental Psychology, 1972, 92, 319-324.

FISHER, M. (Duke Univ., Durham, N.C. 27706), \& KINSBOURNE, M Parallel and competing operations in visual and memory search. Perception \& Psychophysics, 1972 , 11, 350-352.

LIVELY, B. L. (Bowdoin Coll., Brunswick, Maine 04011), \& SANFORD, B. J. The use of 
category information in a memory-search task. Journal of Experimental Psychology, 1972, 93, 379-385.

OSBORNE, J. W. (Univ. of Alberta, Edmonton, Alta., Canada). Shortand long-term memory as a function of individual differences in arousal. Perceptual \& Motor Skills, 1972, 34, 587-593.

PARKS, T. E. (Univ. of California, Davis, Calif. 95616), KROLL, N. E. A., SALZBERG, P. M., \& PARKINSON, S. R. Persistence of visual memory as indicated by decision time in a matching task. Journal of Experimental Psychology, 1972, 92, 437-438.

SNODGRASS, J. G. ( 38 Philosophy Hall, New York Univ., University Heights, Bronx, N.Y. 10453). Matching patterns vs matching digits: The effect of memory dependence and complexity on "same"-"different" reaction times. Perception \& Psychophysics, 1972, $11,341-349$.

\section{LONG-TERM MEMORY}

KEELE, S. W. (Univ. of Oregon, Eugene, Oreg. 97403). Attention demands of memory retrieval. Journal of Experimental Psychology, 1972, 93, 245-248.

NELSON, T. O. (Univ. of Washington, Seattle, Wash. 98195), \& ROTHBART, R. Acoustic savings for items forgotten from long-term memory. Journal of Experimental Psychology, 1972, 93, 357-360.

\section{Recognition Memory}

DANIEL, T. C. (Univ. of Arizona, Tucson, Ariz, 85721), \& ELLIS, $H$. C. Stimulus codability and long-term recognition memory for visual form. Journal of Experimental Psychology, 1972, 93, 83-89.

DEUTSCH, D. (Ctr. for Human Information Processing, Univ, of California, San Diego, La Jolla, Calif. 92037). Effect of repetition of standard and comparison tones on recognition memory for pitch. Journal of Experimental Psychology, 1972, 93, 156-162.

DEUTSCH, D. (Ctr. for Human Information Processing, Univ. of California, San Diego, La Jolla, Calif. 92037). Mapping of interactions in the pitch memory store. Science, 1972, 175, 1020-1022.

DUMAS, J. (Oakland Univ., Rochester, Mich. 48063), GROSS, E., \& CHECKOSKY, S. F. Effects of attribute probability in a memory search task. Journal of Experimental Psychology, 1972, 93, 327-332.

EZINGA, G. (Univ. of Calgary,
Calgary, Alta., Canada), \& ROWLAND, G. L. Accuracy of visual recognition in a complex natural environment. Perceptual \& Motor Skills, 1972, 34, 445-446.

HEIDER, E. R. (Univ. of California, Berkeley, Calif. 94720). Universals in color naming and memory. Journal of Experimental Psychology, 1972, 93, 10-20.

HOPKINS, R. H. (Washington State Univ., Pullman, Wash. 99163), BOYLAN, R. J., \& LINCOLN, G. L. Pronunciation and apparent frequency. Journal of Verbal Learning \& Verbal Behavior, 1972, $11,105-113$.

JACOBY, L. L. (Iowa State Univ., Ames, Iowa 50010). Effects of organization on recognition memory. Journal of Experimental Psychology, 1972, 92, 325-331.

RASER, G. A. (Human Performance Ctr., Univ. of Michigan, Ann Arbor, Mich. 48104). False recognition as a function of encoding dimension and lag. Journal of Experimental Psychology, 1972, 93, 333-337.

SANTA, J. L. (Rutgers Univ., Douglass Coll., New Brunswick, N.J. 08901), \& RANKEN, H. B. Effects of verbal coding on recognition memory. Journal of Experimental Psychology, 1972, 93, 268-278.

WEARING, A. J. (Yale Univ., New $\mathrm{H}$ aven, Conn. 06520 ). Remembering complex sentences. Quarterly Journal of Experimental Psychology, 1972, 24, 77-86.

WINOGRAD, E. (Emory Univ., Atlanta, Ga. 30322), \& RAINES, S. R. Semantic and temporal variation in recognition memory. Journal of Visual Learning \& Verbal Behavior, $1972,11,114-119$.

\section{Recall}

BONE, R. N. (West Virginia Wesleyan Coll., Buckhannon, W. Va. 26201), THOMAS, T. A., \& KINSOLVING, D. L. Relationship of rod-and-frame scores to dream recall. Psychological Reports, 1972, 30, 58 .

CHERNIK, D. A. (Univ. of Pennsylvania, Philadelphia, Pa. 19104). Effect of REM sleep deprivation on learning and recall by humans. Perceptual \& Motor Skills, 1972, 34, 283-294.

COHEN, G. (Inst. of Exptl. Psychol., Univ. of Oxford, Oxford, England). Serial position effects in the recall of picture sequences. Quarterly Journal of Experimental Psychology, 1972, 24, 41-47.

D'AGOSTINO, P. R. (Gettysburg Coll., Gettysburg, Pa. 17325), \& DeREMER, $P$. Item repetition in free and cued recall. Journal of Verbal Learning \& Verbal Behavior, 1972, 11, 54-58.

DONG, T. (Bucknell Univ., Lewisburg,
Pa. 17837). Cued partial recall of categorized words. Journal of Experimental Psychology, 1972, 93, 123-129.

FISHER, D. F. (Ctr. for Vis. Sci. Univ. of Rochester, Rochester, N.Y. 14626), \& KEEN, S. L. Verbal recall as a function of personality characteristic. Journal of Genetic Psychology, 1972, 120, 83-92.

FRITZEN, J. (Virginia Polytech. Inst. \& State Univ., Blacksburg, Va. 24061). Memory search and the recall of digit series. Journal of Experimental Psychology, 1972, 93, 410-416.

HALL, R. F. (Univ. of Sydney, Sydney, N.S.W., Australia 2006), \& WENDEROTH, P. M. Effects of number of responses and recall strategies on parameter values of a paired-associate learning model. Journal of Verbal Learning \& Verbal Behavior, 1972, 11, 29-37.

HARRIS, C. J. (Miami Univ., Oxford, Ohio 45056), \& JAHNKE, J. C. Effect of partial recall on the Ranschburg phenomenon. Journal of Experimental Psychology, 1972, 93, 118-122.

HIPPLE, R. (Univ. of California, Berkeley, Calif. 94720). Retention of paired associates as a function of list length. Journal of Experimental Psychology, 1972, 92, 435-437.

JARVELLA, R. J. (Case Western Reserve Univ., Cleveland, Ohio 44106), \& HERMAN, S. J. Clause structure of sentences and speech processing. Perception \& Psychophysics, 1972, 11, 381-384.

COLE, L. E., \& KANAK, N. J. (Univ. of Oklahoma, Norman, Okla. 73069). Paired-associate learning and bidirectional associative recall in first, third, fifth, and seventh graders. Joumal of Experimental Child Psychology, 1972, 13, 128-137.

KANTOWITZ, B. H. (Purdue Univ., Lafayette, Ind. 47907), ORNSTEIN, P. A., \& SCHWARTZ, M. Encoding and immediate serial recall of consonant strings. Journal of Experimental Psychology, 1972, 93, 105-110.

KENNEDY, A. (Univ. of Dundee, Dundee DD1 $4 \mathrm{HN}$, Angus, Scotland), \& MILNE, M. Cluster analysis of word-order judgment latencies for German active and passive sentences. Psychonomic Science, 1972, 26, 330-332.

KROLL, N. E. A. (Univ. of California, Davis, Calif. 95616). The von Restorff effect as a function of method of isolation. Psychonomic Science, 1972, 26, 333-334.

GOLDSTEIN, J., LOCKE, J. L (Children's Rsch. Ctr., Univ, of Illinois, Champaign, Ill. 61820), \& FEHR, F. S. Children's prerecall 
phonetic processing of pictures and printed words. Psychonomic Science, 1972, 26, 314-316.

McCULLERS, J. C. (Univ. of Oklahoma, Norman, Okla. 73069), \& HALLER, J. Another look at paced versus unpaced recall in free learning. Journal of Experimental Psychology, 1972, 92, 439-440.

RODEWALD, H. K. (Central Michigan Univ., Mount Pleasant, Mich. 48858), \& BOSMA, L. F. Information transmission in brief exposures as a function of association value. Perceptual \& Motor Skills, 1972, 34, 420-422.

WILKES, A. L. (Univ. of Dundee, Dundee, Scotland), LLOYD, P., \& SIMPSON, I. Pause measures during reading and recall in serial list learning. Quarterly Journal of Experimental Psychology, 1972, 24, 48-54.

\section{Free Recall}

ANDERSON, J. R. (Stanford Univ., Stanford, Calif. 94305), \& BOWER, G. H. Recognition and retrieval processes in free recall. Psychological Review, 1972, 79, 97-123.

ROGERS, J. L., \& BATTIG, W. F (Univ. of Colorado, Boulder, Colo. 80302). Effect of amount of prior free recall learning on paired-associate transfer. Journal of Experimental Psychology, 1972, 92, 373-377.

BRUDER, G. (State Univ. of New York, Buffalo, N.Y. 14226), \& SEGAL, E. Effects of temporal and spatial organization of lists on clustering. Journal of Experimental Psychology, 1972, 93, 151-155.

KIBLER, J. L., III, (Univ. of Richmond, Richmond, Va. 23220), \& BLICK, K. A. Evaluation of experimenter-supplied and subject-originated first-letter mnemonics in a free-recall task. Psychological Reports, 1972, 30, 307-313.

ROBERTS, W. A. (Univ. of Western Ontario, London 72, Ont., Canada). Free recall of word lists varying in length and rate of presentation: $A$ test of total-time hypotheses. Journal of Experimental Psychology, 1972, 92, 365-372.

SHAUGHNESSY, J. J. (Northwestern Univ., Evanston, Ill. 60201), Z I M M E R M A N, J ., \& UNDER WOOD, B. J. Further evidence on the MP-DP effect in free-recall learning. Journal of Verbal Learning \& Verbal Behavior, 1972, 11, 1-12.

TULVING, E. (Yale Univ., New Haven, Conn. 06510), \& HASTIE $R$. Inhibition effects of intralist repetition in free recall. Journal of Experimental Psychology, 1972, 92, 297-304.
WEIST, R. M. (Univ. of Nebraska, Lincoln, Nebr. 68508), \& POWELL, A. Blocked presentation in multitrial free recall. Journal of Experimental Psychology, 1972. 93, 398-403.

YOUNG, R. K. (Univ, of Texas, Austin, Tex. 78712), \& BARTON, A. K. Manipulated retrievability in free recall. Journal of Experimental Psychology, 1972, 93, 143-150.

\section{SHORT-TERM MEMORY}

BURROWS, D. (Ctr. for Rsch. in Human Learning, Univ. of Minnesota, Minneapolis, Minn. 55455 ). Modality effects in retrieval of information from short-term memory. Perception \& Psychophysics, 1972, 11, 365-372. GLIDDEN, L. M. (Clarkson Coll. of Tech., Potsdam, N.Y. 13676). Meaningfulness, serial position and retention interval in recognition short-term memory. Journal of Experimental Child Psychology, 1972, 13, 154-164.

KIRSNER, $K$. (Univ. of Toronto, Toronto, Ont., Canada). Developmental changes in short-term recognition memory. British Journal of Psychology, $1972,63,100-117$.

LIVELY, B. L. (Bowdoin Coll., Brunswick, Maine 04011). The von Restorff effect in short-term memory. Journal of Experimental Psychology, 1972, 93, 361-366.

MURDOCK, B. B. (Univ. of Toronto, Toronto, Ont., Canada), DUFTY, P. O., \& OKADA, R. Using the PDP-12 in verbal learning and short-term memory research. Behavior $\mathrm{R}$ e se arch $\mathrm{Methods \quad \&}$ Instrumentation, 1972, 4, 70-71.

REUTENER, D. B. (Smith Coll., Northampton, Mass. 01060). Background, symbolic, and class shift in short-term verbal memory. Journal of Experimental Psychology, 1972, 93, 90-94.

ROSNER, S. R. (Inst. of Child Behav. \& Dev., Univ. of Iowa, Iowa City, Iowa 52240). Primacy in preschoolers' short-term memory: The effects of repeated tests and shift-trials. Journal of Experimental Child Psychology, 1972, 13, 220-230.
SCHUTZ, S R. (Gordon Coll. Wenham, Mass. 01984), \& KEISLAR, E. R. Young children's immediate memory of word classes in relation to social class. Journal of Verbal Learning \& Verbal Behavior. $1972,11,13-17$.

TAUB, H. A. (VA Hosp. \& Syracuse Psychiat. Hosp., Syracuse, N.Y. 13210). A further study of aging, short-term memory, and complexity of stimulus organization. Journal of Genetic Psychology, 1972, 120, 163-164

TRUMBO, D. (Pennsylvania State Univ., University Park, Pa. 16802), MILONE, F., \& NOBLE, M. Interpolated activity and response mechanisms in motor short-term memory. Journal of Experimental Psychology, 1972, 93, 205-212.

WARRINGTON, E. K. (National Hosp., Queen Sq., London, W.C.1, England ), \& SHALLICE, T. Neuropsychological evidence of visual storage in short-term memory tasks. Quarterly Joumal of Experimental Psychology, 1972, 24, 30-40.

\section{TRANSFER}

BIRNBAUM, I. M. (Sch. of Soc. Sci. Univ. of California, Irvine, Calif. 92664). General and specific components of retroactive inhibition in the A-B, A-C paradigm. Journal of Experimental Psychology, 1972, 93, 188-192.

NELSON, D. L. (Univ. of South Florida, Tampa, Fla. 33620), \& DAVIS, M. J. Transfer and false recognitions based on phonetic identities of words. Journal of Experimental Psychology, 1972, 92, 347-353.

POSTMAN, L. (Univ. of California, Berkeley, Calif. 94720), \& WARREN, L. Temporal changes in interference under different paradigms of transfer. Journal of Verbal Learning \& Verbal Behavior, $1972,11,120-128$

SLAMECKA, N. J. (Univ. of Toronto, Toronto 181, Ont., Canada), MOORE, T., \& CAREY, S Part-to-whole transfer and its relation to organization theory Journal of Verbal Learning \& Verbal Behavior, 1972, 11, 73-82.

\section{HUMAN THINKING}

COHEN, J. (Univ. of Manchester, Manchester, England), CHESNICK, E. I., \& HARAN, D. A confirmation of the intertrial- $\psi$ effect in sequential choice and decision British Journal of Psychology, 1972, 63, 41-46.

JONES, B. M. (Ctr. for Alcohol-Related Studies, Univ. of
Oklahoma Health Sci. Ctr. Oklahoma City, Okla. 73190). Cognitive performance during acute alcohol intoxication: The effects of prior task experience on performance. Psychonomic Science, 1972, 26, 327-329.

J O E S, B. M. (Ctr. for Alcohol-Related Studies, Dept. of 
Psychiat. \& Behav. Sci., Univ. of Oklahoma Med Ctr., Oklahoma City, Okla. 73100), \& VEGA, A. Cognitive performance measured on the ascending and descending limb of the blood alcohol curve. Psychopharmacologia (Berlin), 1972, 23, 99-114.

KREITLER, H. (Tel-Aviv Univ., Tel-Aviv, Israel), \& KREITLER, S. The model of cognitive orientation: Towards a theory of human behaviour. British Journal of Psychology, 1972, 63, 9-30.

OLIVE, H. (Skyview Dr., R. D. Hopewell, N.J. 08525). Sibling resemblances in divergent thinking. Journal of Genetic Psychology, $1972,120,155-162$.

RESTLE, F. (Indiana Univ., Bloomington, Ind. 47401). Serial patterns: The role of phrasing. Journal of Experimental Psychology, 1972, 92, 385-390.

SHANTEAU, J. (Kansas State Univ., Manhattan, Kans. 66502). Descriptive versus normative models of sequential inference judgment. Journal of Experimental Psychology, 1972, 93,63-68.

LANDON, P. B., \& SUEDFELD, P. (Rutgers-The State Univ., New Brunswick, N.J. 08903). Complex cognitive performance and sensory deprivation: Completing the U-curve. Perceptual \& Motor Skills, $1972,34,601-602$.

\section{VERBAL PROCESSES}

CERMAK, L. S. (Tufts Univ., Boston, Mass. 02155), SAGOTSKY, G., \& MOSHIER, C. Development of the ability to encode within evaluative dimensions. Journal of Experimental Child Psychology, 1972, 13, 210-219.

DONDERI, D. (McGill Univ., Montreal, P.Q., Canada), \& MILLER, B. Luminous targets: Visibility fluctuations modified by similar verbal responses. Perception \& Psychophysics, 1972, 11, 299-300.

DYER, F. N. (U.S. Army Med. Rsch. Lab., Fort Knox, Ky. 40121). Latencies for movement naming with congruent and incongruent word stimuli. Perception \& Psychophysics, 1972, 11, 377-380.

KLAPP, S. T. (California State Coll., Hayward, Calif. 94542), \& BISCHOFF, D. M. Does implicit speech in same-different decisions extend to nonsense forms? Perception \& Psychophysics, 1972, $11,363-364$.

KOUTSTAAL, C. W. (Bowling Green State Univ., Bowling Green, Ohio 43402), SMITH, O. W., \& KNOPS, L. Intercorrelation of Greenberg and Jenkins' $S$ scale and effort ratings of phonemic CCVCs by Ss from different groups of languages. Perceptual \& Motor Skills, 1972, 34, 655-658.

SANTA, J. L. (Rutgers Univ., Douglass Coll., New Brunswick, N.J. 08901), \& RANKEN, H. B. Effects of verbal coding on recognition memory. Journal of Experimental Psychology, 1972, 93, 268-278.

SODERBERG, G. A. (Univ. of California, Los Angeles, Calif. 90024 ), \& MacKAY, D. G. The function relating stuttering to phoneme frequency and transition probability. Journal of Verbal Learning \& Verbal Behavior, 1972, $11,83-91$.

\section{Word Association}

BREZNITZ, S. (Hebrew Univ., Jerusalem, Israel). Self-produced context effect in word association. Psychological Reports, 1972, 30, 299.306.

HALL, J. W. (Northwestern Univ. Sch. of Ed., Evanston, Ill. 60201), \& CROWN, I. Associative encoding of words in sentences by adults and children. Journal of Verbal Learning \& Verbal Behavior, 1972, 11, 92-95.

H OWE, E. S. (Univ. of Missouri-St. Louis, St. Louis, Mo. 63121). Number of different free associates: A general measure of associate meaningfulness. Journal of Verbal Learning \& Verbal Behavior, 1972, 11, 18-28.

INNES, J. M. (Univ. of Birmingham, Birmingh am, England). Word-association response commonality and the generation of associative structures. British Journal of Psychology, 1972, 63, 63-72.

KOUTSTAAL, C. W. (Bowling Green State Univ., Bowling Green, Ohio 43402), \& SMITH, O. W. (Relation of meaningfulness to the distance from English of phonemic CCVCs. Perceptual \& Motor Skills, 1972, $34,647-651$.

KAHANA, B., \& STERNECK, R. (St. Louis Univ., St. Louis, Mo. 63103). Word-association responses of children as a function of age, sex, and instructions. Journal of Genetic Psychology, 1972, 120, 39-48.

STOLZ, W. S. (Earlham Coll. Richmond, Ind. 47374), \& TIFFANY, J. The production of "child-like" word associations by adults to unfamiliar adjectives. Journal of Verbal Learning \& Verbal Behavior, 1972, 11, 38-46.

\section{Language}

DEGERMAN, R. (Dartmouth Coll., Hanover, N.H. 03755), \& MATHIER, R. S. Spatial representation of noun phrases. Journal of Verbal Learning \& Verbal Behavior, 1972, 11, 66-72.
DOOLING, D. J. (Kent State Univ., Kent, Ohio 44240). Some context effects in the speeded comprebension of sentences. Journal of Experimental Psychology, 1972, 93, 56-62.

JARVELLA, R. J. (Case Western Reserve Univ., Cleveland, Ohio 44106), \& SINNOTT, J. Contextual constraints on noun distributions to some English verbs by children and adults. Journal of Verbal Learning \& Verbal Behavior, 1972, 11, 47-53.

STEINBERG, D. D. (Dept. of English as a Second Language, Univ. of Hawaii, Honolulu, Hawaii 96822). Truth, amphigory, and the semantic interpretation of sentences. Journal of Experimental Psychology, 1972, 93, 217-218.

SUSSMAN, H. M. (Dept. of Linguistics, Univ. of Texas, Austin, Tex. 78712). What the tongue tells the brain. Psychological Bulletin, $1972,77,262-272$.

\section{PROBLEM SOLVING}

CVETKOVICH, G. (Ctr. for Cross Cultural Rsch., Western Washington State Coll., Bellingham, Wash. 98225). Effects of sex on decision policies used for self and decision policies used for other persons. Psychonomic Science, 1972, 26, 319-320.

DOMINOWSKI, R. L. (Univ. of Illinois at Chicago Circle, Chicago, $\mathrm{Il}$. 60680), \& JENRICK, R. Effects of hints and interpolated activity on solution of an insight problem. Psychonomic Science, 1972, 26, 335-338.

LeMAY, E. H. (Plattsburgh State Univ. Coll. of Arts \& Sci., Plattsburgh, N.Y. 12901 ). Stimulus generalization variables in anagram-problem solving. Journal of Experimental Psychology, 1972, 93, 349-353.

MAIER, N. R. F. (Univ. of Michigan, Ann Arbor, Mich. 48104). Effects of training on decision-making. Psychological Reports, 1972, 30, 159-164.

RAAHEIM, K. (Inst. of Psychol., Univ. of Bergen, Norway), \& KAUFMANN, G. Level of activity and success in solving an unfamiliar task. Psychological Reports, 1972, 30, 271-274.

REITAN, R. M. (Child Dev. \& Mental Retardation Ctr., Univ. of Washington, Seattle, Wash. 98195). Verbal problem solving as related to cerebral damage. Perceptual \& Motor Skills, 1972, 34, 515-524.

\section{CONCEPTS}

AIKEN, L. S. (Temple Univ., Philadelphia, Pa. 19122), SANTA, J. L., \& RUSKIN, A. B. 
Nonreinforced trials in concept identification: Presolution statistics and local consistency. Journal of Experimental Psychology, 1972, 93, 100-104.

COLTHEART, V. (Univ. of Guelph, Guelph, Ont., Canada). The effects of acoustic and semantic similarity on concept identification. Quarterly Journal of Experimental Psychology, 1972, 24, 55-65.

JANKE, M. (Stockton State Hosp., 510 E. Magnolia St., Stockton, Calif. 95202). Effect of stimulus and instructional variables in an ambiguous concept-attainment task. Journal of Experimental Psychology, 1972, 93, 21-29.

ROSENTHAL, T. L. (Univ. of Arizona, Tucson, Ariz. 85721), ALFORD, G. S., \& RASP, L. M.

\section{HUMAN DEVELOPMENT}

ASHTON, R. (Univ. of Lagos, Lagos, Nigeria). State and the auditory reactivity of the human neonate. Journal of Experimental Child Psychology, 1971, 12, 339-346.

BOND, E. K. (H. Pollak Clin., Monmouth Med. Ctr., Long Branch, N.J. 07740). Perception of form by the human infant. Psychological Bulletin, 1972, 77, 225-245.

CERMAK, L. S. (Tufts Univ., Boston, Mass. 02155), SAGOTSKY, G., \& MOSHER, C. Development of the ability to encode within evaluative dimensions. Journal of Experimental Child Psychology, $1972,13,210-219$.

GUMMERMAN, K. (Univ. of Texas, Austin, Tex. 78712), \& GRAY, C. $\mathrm{R}$. Age, iconic storage, and visual information processing. Journal of
Concept attainment, generalization, and retention through observation and verbal coding. Journal of Experimental Child Psychology, 1972, 13, 183-194.

HEIM, S. V., \& SCHOLNICK, E. K. (Univ. of Maryland, College Park, Md. 20742). Some hypotheses about negative instances in single-attribute concept attainment. Journal of Experimental Psychology, 1972, 93, 130-137.

THOMSON, W. J. (Vanderbilt Univ., Nashville, Tenn. 37203). Effect of number of response categories on d i m ension selection, paired-associate learning, and complete learning in a conjunctive concept identification task. Journal of Experimental Psychology, 1972, 93, 95-99.

KIRSNER, K. (Univ. of Toronto, Toronto, Ont., Canada). Developmental changes in short-term recognition memory. British Journal of Psychology, 1972, 63, 109-117.

NICHOLSON, J. N. (Univ. of Reading, Reading, England), \& GRAY, J. A. Peak shift, behavioural contrast and stimulus generalization as related to personality and development in children. British Journal of Psychology, 1972, 63, 47-62.

RANDHAWA, B. S. (Univ. of Saskatchewan, Saskatoon, Canada). Nonverbal information storage in children and developmental information processing channel capacity. Journal of Experimental Child Psychology, 1972, 13, 58-70.

ROSS, H. S. (Univ. of North Carolina, Chapel Hill, N.C. 27514), R H E I G O L D, H. L., \& ECKERMAN, C. O. Approach and exploration of a novel alternative by 12-month-old infants. Journal of Experimental Child Psychology, 1972, 13, 165-170.

JARVELLA, R. J. (Case Western Reserve Univ., Cleveland, Ohio 44106), \& SINNOT, J. Contextual constraints on noun distributions to some English verbs by children and adults. Journal of Verbal Learning \& Verbal Behavior, 1972, 11, 47-53.

COLE, L. E., \& KANAK, N. J. (Univ. of Oklahoma, Norman, Okla. 73069). Paired-associate learning and bidirectional associative recall in first, third, fifth, and seventh graders. Journal of Experimental Child Psychology, 1972, 13, 128-137.

KEENAN, V. (Univ. of Colorado, Boulder, Colo. 80302). Effects of Hebrew and English letters on children's perceptual set. Journal of Experimental Child Psychology, $1972,13,71-84$.
Experimental Child Psychology, 1972, 13, 85-93.

THOMAS, J. R. (Div. of Health, Phys. Ed. \& Rec., Georgia Southern Coll., Statesboro, Ga. 30458), \& CHISSOM, B. S. Relationships as assessed by canonical correlation between perceptual-motor and intellectual abilities for pre-school and early elementary age children. Journal of Motor Behavior, 1972, 4, 23-29.

TRONICK, E. (Children's Hosp. Med. Ctr., 300 Longwood Ave., Boston, Mass. 02115). Stimulus control and the growth of the infant's effective visual field. Perception \& Psychophysics, 1972, 11, 373-376. ZELAZO, P. R. (Dept. of Soc. Rel., Harvard Univ., Cambridge, Mass. 02138), ZELAZO, N. A., \& KOLB, S. "Walking" in the newborn. Science, 1972, 176, 314-315. 